\title{
Penetapan Harga Pokok Produksi Kacang Koro Pedang pada UD Laksmi Devi
}

\author{
NI WAYAN LIA WIDYANTARI, I KETUT SUAMBA, \\ IDA AYU LISTIA DEWI \\ Program Studi Agribisnis, Fakultas Pertanian, Universitas Udayana \\ Jalan PB. Sudirman Denpasar 80323 \\ Email: liawidyantari8@gmail.com \\ suamba_unud@yahoo.co.id
}

\section{Abstract \\ Determination of Cost of Goods Manufactured of Jack Beans on UD Laksmi Devi}

UD Laksmi Devi is an agro-industrial processing of jack beans. The business competition is high, so it is necessary to establish the appropriate best selling price of product through analysis of cost of goods manufactured price of jack beans. This study aims to find out the cost of jack beans manufactured by UD Laksmi Devi, The result of calculation of the cost of goods manufactured based on the components of production costs and non-production costs, compare the difference in the calculation of cost of production from both analysis, and show sensitivity of cost to cost of goods of jack beans manufactured with sensitivity analysis. Analysis of cost of goods manufactured are calculated only one month, namely December 2016. Calculation of the cost of goods manufactured per unit by UD Laksmi Devi Rp 28.887,33, while the value through the analysis of cost of goods manufactured that takes into account the components of production and non-production costs amount to Rp 31.529,83. Component of costs incurred by UD Laksmi Devi only production costs, making it look bigger profits of $\mathrm{Rp} 22.005 .612$, compared by researched in the analysis of cost of goods manuafactured only $\mathrm{Rp} 12.492 .612$. The difference shows that the analysis of cost of goods manufactured based on production costs and non-production costs is good to applicate because the costs are detailed, so the cost of good manufactured are accurate as the basic for determining the selling price of jack beans in UD Laksmi Devi.

Keywords: jack beans, cost of goods manufactured, production costs, nonproduction costs.

\section{Pendahuluan}

\section{$1.1 \quad$ Latar Belakang}

Indonesia memiliki banyak potensi diantaranya dari $1.904 .569 \mathrm{~km}^{2}$ luas wilayahnya, sebagian besar merupakan lahan pertanian. Indonesia juga menempati urutan ke-4 di tahun 2015 dari seluruh negara yang ada di dunia sebagai negara dengan jumlah penduduk terbanyak, yakni sebesar 258.316.051 jiwa (BPS, 2016). Potensi lainnya yakni iklim tropis yang membuat banyak sekali tanaman yang bisa 
dibudidayakan termasuk kacang-kacangan yang bisa diolah kedalam beragam jenis makanan (Balitkabi, 2016). Seiring dengan perkembangan era globalisasi, potensipotensi tersebut justru tidak termanfaatkan secara optimal. Setiap individu dituntut untuk memenuhi kebutuhan yang semakin beragam. Kemajuan teknologi membuat sebagian besar masyarakat selalu menginginkan segala sesuatu dengan cepat dan praktis. Agroindustri sebagai salah satu perusahaan pengolahan terutama makanan, mengambil peluang dari permasalahan tersebut. Agroindustri menurut Soekartawi (2011) merupakan pemanfaatan hasil komoditi pertanian menjadi sesuatu yang memiliki nilai tambah menuangkan kreativitas dan inovasinya agar bisa memenuhi kebutuhan hidup manusia disamping tujuannya untuk meraup keuntungan.

UD Laksmi Devi merupakan salah satu agroindustri yang bergerak di bidang pengolahan kacang koro pedang yang diproduksi berdasarkan pesanan, yang terletak di Desa Nyanglan, Kecamatan Banjarangkan, Kabupaten Klungkung. UD Laksmi Devi mengalami persaingan usaha sejenis di lokasi berdirinya agroindustri tersebut, hal ini disebabkan karena Desa Nyanglan merupakan sentra pengolahan kacang koro pedang. Pemilik usaha, apapun jenisnya harus menyadari bahwa dalam dunia usaha akan selalu ada persaingan baik perusahaan sejenis maupun berbeda jenis. Peraturan mengenai larangan praktek monopoli dan persaingan usaha tidak sehat yang tercantum pada UU No 5 Tahun 1999 sebagai dasar hukum persaingan usaha di Indonesia sudah ditetapkan, tetapi persaingan usaha yang terjadi tetap saja sangat mengkhawatirkan. Adanya persaingan usaha tidak lain alasannya karena tingkat keuntungan maksimum yang ingin didapatkan oleh setiap perusahaan. Harga menurut Kotler dan Amstrong (dalam Rezki, 2014) yang merupakan sejumlah uang yang dibebankan atas suatu produk atau jasa atau jumlah dari nilai yang ditukar konsumen atas manfaat-manfaat karena memiliki atau menggunakan produk atau jasa. Definisi serupa juga dikemukakan oleh William J Stanton (dalam Mukhyi, 2015), dimana harga adalah jumlah uang yang dibutuhkan untuk mendapatkan sejumlah kombinasi dari barang beserta pelayanannya. Kedua pengertian tersebut menunjukkan harga menjadi unsur paling penting yang wajib diperhitungkan oleh pemilik usaha ditengah gencarnya persaingan yang terjadi serta tingkat keuntungan maksimum yang ingin didapatkan.

UD Laksmi Devi memperhitungkan harga jual produk dengan menjadikan perhitungan harga pokok produksi sebagai acuan. UD Laksmi Devi menentukan harga pokok produksi dengan memperhitungkan komponen biaya produksi yang belum terinci secara detail, dan untuk tenaga kerja non produksi juga dimasukkan kedalam biaya produksi. Sesuai dengan apa yang telah diperhitungkan UD Laksmi Devi, agar diperoleh harga pokok produksi yang akurat, maka diperlukan analisis harga pokok produksi dengan mengelompokkan komponen biaya secara detail. Perhitungan harga pokok produksi yang akan dilihat perbedaannya dalam penelitian ini hanya bulan Desember 2016 saja, karena berdasarkan hasil wawancara dan data yang diperoleh pada bulan Desember dilakukan pengoptimalan produksi berdasarkan 
sisa bahan baku utama dan perhitungan beberapa kondisi seperti perayaan Natal dan Tahun Baru yang membuat jumlah produksi menjadi meningkat.

Berdasarkan uraian permasalahan diatas, maka peneliti melakukan penelitian tentang penetapan harga pokok produksi kacang koro pedang pada UD Laksmi Devi dan melihat tingkat kepekaan beberapa biaya terhadap harga pokok produksi kacang koro pedang.

\subsection{Rumusan Masalah}

Berdasarkan latar belakang yang telah diuraikan, maka yang menjadi rumusan masalah dalam penelitian ini adalah sebagai berikut:

1. Bagaimana perhitungan harga pokok produksi (HPP) untuk produk kacang koro pedang yang dilakukan oleh UD Laksmi Devi ?

2. Bagaimana analisis harga pokok produksi (HPP) kacang koro pedang di UD Laksmi Devi dengan memperhitungkan komponen biaya produksi dan biaya non produksi?

3. Bagaimana perbedaan hasil perhitungan harga pokok produksi (HPP) kacang koro pedang menurut UD Laksmi Devi dan analisis harga pokok produksi dengan memperhitungkan biaya produksi serta non produksi dan bagaimana analisis kepekaan biaya kacang koro pedang UD Laksmi Devi terhadap harga pokok produksinya?

\subsection{Tujuan Penelitian}

Sesuai dengan rumusan masalah diatas, maka tujuan dari penelitian ini adalah sebagai berikut:

1. Untuk mengetahui perhitungan harga pokok produksi (HPP) produk kacang koro pedang yang dilakukan oleh UD Laksmi Devi.

2. Untuk mengetahui analisis harga pokok produksi (HPP) kacang koro pedang di UD Laksmi Devi dengan memperhitungkan komponen biaya produksi dan biaya non produksi.

3. Untuk mengetahui perbedaan hasil perhitungan harga pokok produksi (HPP) kacang koro pedang menurut UD Laksmi Devi dan analisis harga pokok produksi dengan memperhitungkan biaya produksi serta non produksi dan mengetahui analisis kepekaan biaya kacang koro pedang UD Laksmi Devi terhadap harga pokok produksinya.

\section{Metode Penelitian}

\subsection{Lokasi dan Waktu Penelitian}

Penelitian ini dilakukan di UD Laksmi Devi yang berlokasi di Dusun Tengah, Desa Nyanglan, Kecamatan Banjarangkan, Kabupaten Klungkung, Bali. Penelitian dilaksanakan dari bulan Maret sampai April 2017. Pemilihan Lokasi penelitian dilakukan dengan sengaja menggunakan metode purposive sampling. Metode 
purposive yaitu suatu metode penentuan daerah penelitian secara sengaja atas pertimbangan-pertimbangan tertentu.

\subsection{Jenis dan Sumber Data}

Menurut Ulfiarahmi (2011), jenis data yang digunakan dalam penelitian ini yaitu (1) data kuantitatif yang diperlukan adalah informasi keuangan diantaranya kebutuhan pesanan, jumlah karyawan, kuantitas bahan baku, total produksi, biaya tenaga kerja langsung, biaya lain-lain, biaya pemasaran, biaya administrasi, biaya bahan penolong, biaya pemeliharaan, dan biaya penyusutan serta (2) data kualitatif yang menjelaskan gambaran umum UD Laksmi Devi seperti profil, sejarah, struktur organisasi, dan alur proses pengolahan produk kacang koro pedang. Sumber data dalam penelitian ini, yaitu (1) data primer bersumber dari pemilik UD Laksmi Devi, dan bagian keuangan serta (2) data sekunder diperoleh dari sumber-sumber terpercaya melalui wawancara, internet dan beberapa literatur yang berkaitan dengan penelitian ini.

\subsection{Informan Kunci}

Penelitian ini menggunakan informan kunci yang dipilih secara sengaja untuk mendapatkan informasi dan kebutuhan data dalam penelitian tentang penentuan harga pokok produksi Informan kunci dianggap sudah mampu menjangkau segala kebutuhan data yang dibutuhkan oleh peneliti. Winarno (dalam Bungin, 2014) kembali menegaskan bahwa tidak semua penelitian memerlukan sampel penelitian. Informan kunci dalam penelitian ini adalah pimpinan UD Laksmi Devi dan bagian keuangan.

\subsection{Metode Pengumpulan Data}

Metode pengumpulan data dilakukan dengan (1) Survey, merupakan pencarian serta pengumpulan data primer dengan cara memberikan pertanyaan kepada narasumber melalui daftar pertanyaan, (2) Wawancara mendalam adalah proses mencari informasi, keterangan dan kebutuhan data secara detail untuk mencapai tujuan penelitian dengan cara tanya jawab sambil bertatap muka antara pewawancara dengan responden (Nazir dalam Bungin, 2014), dan (3) Metode penelusuran data online, adalah tata cara melakukan penelusuran data melalaui media online seperti internet atau media jaringan lainnya yang menyediakan fasilitas online, sehingga memungkinkan peneliti untuk dapat memanfaatkan data atau informasi online yang berupa data maupun informasi teori, secepat atau semudah mungkin dan dapat dipertanggungjawabkan secara akademis.

\subsection{Variabel Penelitian dan Pengukuran}

Variabel dalam penelitian ini adalah harga pokok produksi. Indikator yang digunakan dalam penelitian antara lain kebutuhan pesanan, jumlah karyawan, kuantitas bahan baku, total produksi, biaya tenaga kerja langsung, biaya lain-lain, 
biaya pemasaran, dan biaya administrasi. Parameter penelitian yang digunakan sesuai dengan indikator yang digunakan. Indikator biaya menggunakan parameter jumlah/bulan, jumlah/hari, dan jumlah/pesanan dengan pengukuran Rp/bulan, $\mathrm{Rp} / \mathrm{hari}$, dan Rp/pesanan. Kuantitas bahan baku, jumlah pesanan, serta jumlah karyawan menggunakan parameter jumlah dengan pengukuran menyesuaikan dengan indikator masing-masing.

\subsection{Metode Analisis Data}

Metode analisis data yang digunakan dalam penelitian ini adalah analisis deskriptif kuantitatif dengan menggunakan analisis harga pokok produksi. Tujuan penggunaan analisis tersebut adalah untuk mengetahui perbandingan hasil perhitungan harga pokok produksi kacang koro pedang yang dilakukan UD Laksmi Devi dengan analisis harga pokok produksi yang memperhitungkan komponen biaya produksi dan biaya non produksi. Analisis tambahan yang digunakan dalam penelitian adalah analisis sensitivitas untuk mengetahui tingkat kepekaan beberapa biaya terhadap harga pokok produksi kacang koro pedang.

\section{Hasil dan Pembahasan}

\subsection{Perhitungan Harga Pokok Produksi (HPP) Kacang Koro Pedang yang Dilakukan UD Laksmi Devi}

Perhitungan harga pokok produksi kacang koro pedang yang dilakukan UD Laksmi Devi hanya mengelompokkan biaya kedalam biaya produksi semata. Komponen biaya produksi yang dimasukkan ke dalam perhitungan sesuai dengan klasifikasi biaya produksi menurut Hansen dan Mowen (1999) yang terdiri atas tiga komponen biaya utama yaitu biaya bahan langsung, biaya tenaga kerja langsung, dan biaya overhead. Dalam hal ini yang dimaksudkan biaya overhead oleh UD Laksmi Devi adalah biaya listrik dan biaya air. Hasil perhitungan harga pokok produksi kacang koro pedang bulan Desember 2016 yang dilakukan UD Laksmi Devi dapat dilihat pada tabel berikut ini :

\section{Tabel 1.}

Perhitungan Harga Pokok Produksi UD Laksmi Devi Desember 2016

\begin{tabular}{lr}
\hline \multicolumn{1}{c}{ Keterangan } & Total biaya (Rp) \\
\hline Biaya bahan langsung & $85.120 .000,00$ \\
Biaya tenaga kerja langsung & $18.330 .000,00$ \\
Biaya listrik dan air & $544.402,74$ \\
Total harga pokok produksi Desember 2016 & $103.994 .402,74$ \\
Total harga pokok produksi per unit & $28.887,33$ \\
\hline
\end{tabular}

Sumber: diolah dari data primer

Tabel 1 menunjukkan bahwa perhitungan harga pokok produksi yang dilakukan oleh UD Laksmi Devi hanya memperhitungkan biaya bahan langsung, 
biaya tenaga kerja langsung, biaya listrik, dan biaya air. Bahan penolong diluar bahan baku utama (kacang koro pedang) dimasukkan ke dalam biaya bahan langsung. Biaya tenaga kerja pengiriman yang seharusnya merupakan komponen biaya non produksi dalam hal ini dimasukkan ke dalam biaya tenaga kerja langsung. Total biaya yang dikeluarkan pada bulan Desember tahun 2016 sesuai tabel diatas adalah Rp 103.994.402,74. Harga pokok produksi per kg kacang koro pedang sebesar Rp 28.887,33 dengan total unit yang diproduksi sebanyak $3.600 \mathrm{~kg}$. Harga jual produk yang ditetapkan berada diatas harga pokok produksi yaitu Rp 35.000, maka UD Laksmi Devi mendapatkan laba untuk setiap unit kacang koro pedang sebesar Rp $6.112,67$. Total laba yang diperoleh pada bulan tersebut berdasarkan perhitungan UD Laksmi Devi sebesar Rp 22.005.612.

\subsection{Analisis Harga Pokok Produksi Kacang Koro Pedang di UD Laksmi Devi dengan Komponen Biaya Produksi dan Biaya Non Produksi}

UD Laksmi Devi melaksanakan proses produksi kacang koro pedang berdasarkan pesanan. Sekilas karakteristik agroindustri memenuhi kriteria penerapan harga pokok pesanan, namun setelah ditelusuri pembelian bahan baku hanya sekali dalam setahun, sehingga membuat harga pokok pesanan bukan metode yang tepat untuk diterapkan. Menurut Mulyadi (dalam Murti, 2015), metode harga pokok pesanan adalah cara penentuan harga pokok produk di mana biaya-biaya produksi dikumpulkan untuk pesanan tertentu dan harga pokok produksi per satuan dihitung dengan cara membagi total biaya produksi untuk pesanan tersebut dengan jumlah satuan produk dalam pesanan yang bersangkutan. Penentuan harga pokok produksi yang tepat diaplikasikan di UD Laksmi Devi adalah dengan mengelompokkan biaya kedalam biaya produksi dan non produksi. Hansen dan Mowen (1999) menyebutkan yang tergolong ke dalam biaya produksi adalah biaya bahan langsung, biaya tenaga kerja langsung, dan biaya overhead. Komponen yang tergolong biaya non produksi secara umum adalah biaya administrasi dan biaya penjualan atau pemasaran. Hasil perhitungan harga pokok produksi kacang koro pedang UD Laksmi Devi bulan Desember 2016 dapat dilihat pada tabel berikut: 
Tabel 2.

Analisis Harga Pokok Produksi Kacang Koro Pedang Berdasarkan Biaya Produksi dan Non Produksi UD Laksmi Devi Desember 2016

\begin{tabular}{lr}
\hline \multicolumn{1}{c}{ Unsur biaya } & Total biaya $(\mathrm{Rp})$ \\
\hline Biaya produksi & \\
Biaya bahan langsung & $24.000 .000,00$ \\
Biaya tenaga kerja langsung & $16.800 .000,00$ \\
Biaya overhead pabrik & $62.023 .285,41$ \\
Total biaya produksi & $102.823 .285,41$ \\
Biaya non produksi & \\
Biaya pemasaran & $3.230 .000,00$ \\
Biaya administrasi & $105.000,00$ \\
Biaya tenaga kerja tidak langsung & $4.500 .000,00$ \\
Biaya pajak & $2.849 .100,00$ \\
Total biaya non produksi & $10.684 .100,00$ \\
Harga pokok produksi Desember 2016 & $113.507 .385,41$ \\
Harga pokok produksi per kg & $31.529,83$ \\
\hline
\end{tabular}

Sumber: diolah dari data primer

Tabel 2 menunjukkan total harga pokok produksi kacang koro pedang UD Laksmi Devi bulan Desember tahun 2016 sebesar Rp 113.507.385,41. Harga pokok produksi per kg senilai Rp 31.529,83 dimana kebutuhan pesanan sebanyak $3.600 \mathrm{~kg}$ dengan harga jual Rp 35.000/kg, sehingga laba per unit yang diperoleh pada bulan tersebut sebesar Rp 3.470,17. Total keuntungan atau laba yang diperoleh pada bulan tersebut sebesar Rp 12.492.612. Harga pokok produksi per unit yang dihitung berdasarkan komponen biaya produksi dan non produksi masih berada dibawah harga jual produk per unit, sehingga bisa dipastikan UD Laksmi Devi tidak mengalami kerugian.

\subsection{Perbedaan Perhitungan Harga Pokok Produksi Kacang Koro Pedang UD Laksmi Devi dan Analisis Harga Pokok Produksi dengan Biaya Produksi dan Non Produksi serta Analisis Kepekaan Biaya}

Setiap unit usaha wajib melaksanakan perhitungan harga pokok produksi kembali untuk memastikan perhitungan sesungguhnya berada dibawah harga jual produk karena banyak kasus menunjukkan setiap unit usaha tidak mengenali komponen biaya terutama biaya produksi termasuk UD Laksmi Devi. Penelitian di UD Laksmi Devi ini membandingkan hasil perhitungan untuk melihat selisih masing-masing unsur biaya dalam harga pokok produksi. Perbedaan tersebut dapat dilihat pada tabel berikut ini: 


\section{Tabel 3.}

Perhitungan Harga Pokok Produksi Kacang Koro Pedang

UD Laksmi Devi dengan Analisis Harga Pokok Produksi Berdasarkan Komponen

Biaya Produksi dan Non Produksi Desember 2016

\begin{tabular}{clcr}
\hline No & \multicolumn{1}{c}{ Unsur biaya } & $\begin{array}{c}\text { UD Laksmi Devi } \\
(\mathrm{Rp})\end{array}$ & $\begin{array}{c}\text { Harga pokok } \\
\text { produksi (Rp) }\end{array}$ \\
\hline 1 & Biaya bahan langsung & $85.120 .000,00$ & $24.000 .000,00$ \\
2 & Biaya tenaga kerja langsung & $18.330 .000,00$ & $16.800 .000,00$ \\
3 & Biaya overhead pabrik & $544.402,74$ & $62.023 .285,41$ \\
4 & Biaya non produksi & - & $10.684 .100,00$ \\
5 & Harga pokok produksi bulan & $103.994 .402,74$ & $113.507 .385,41$ \\
& Desember 2016 & & \\
6 & Jumlah produksi (kg) & $3.600,00$ & $3.600,00$ \\
7 & Harga pokok produksi per kg & $28.887,33$ & $31.529,83$ \\
8 & Harga jual per kg & $35.000,00$ & $35.000,00$ \\
9 & Keuntungan per kg & $6.112,67$ & $3.470,17$ \\
10 & Keuntungan pada Desember 2016 & $22.005 .612,00$ & $12.492 .612,00$ \\
\hline
\end{tabular}

Sumber: diolah dari data primer

Tabel 3 menunjukkan bahwa terdapat selisih yang cukup besar di masingmasing komponen biaya. Biaya bahan langsung yang dimasukkan berdasarkan analisis harga pokok produksi yang diteliti hanya bahan baku utama yaitu kacang koro pedang. Biaya tenaga kerja langsung yang dimasukkan dalam analisis hanya tenaga kerja dalam proses produksi yaitu tahap kegiatan satu dan tahap kegiatan dua, sedangkan yang diperhitungkan UD Laksmi Devi memasukkan tenaga kerja pengiriman kedalam tenaga kerja langsung sebagai komponen biaya produksi. Biaya overhead pabrik yang dimasukkan kedalam perhitungan berdasarkan analisis tersebut sesuai dengan pendapat Simamora (1999) yang terdiri atas biaya bahan penolong, biaya listrik, biaya air, biaya pemeliharaan, serta biaya penyusutan. Biaya non produksi yang diperhitungkan dalam analisis tersebut adalah biaya pemasaran, biaya administrasi, biaya tenaga kerja tidak langsung, dan biaya pajak.

Tingkat keuntungan dari kedua perhitungan juga menunjukkan selisih yang terpaut jauh. Tingkat keuntungan yang didapatkan berdasarkan analisis yang diteliti merupakan keuntungan bersih, karena semua biaya telah diperhitungkan. Perhitungan UD Laksmi Devi menunjukkan tingkat keuntungan yang diperoleh tergolong keuntungan kotor, dimana ada kemungkinan biaya lain yang harus dibayarkan karena perincian biaya yang tidak detail. 
Tabel 4.

Analisis Kepekaan Biaya terhadap Harga Pokok Produksi Kacang Koro Pedang UD Laksmi Devi

\begin{tabular}{ccc}
\hline \multirow{2}{*}{$\begin{array}{c}\text { Skenario } \\
\text { (asumsi) }\end{array}$} & \multicolumn{2}{c}{ Harga Pokok Produksi } \\
\cline { 2 - 3 } & Per Bulan $(\mathrm{Rp})$ & Per Unit $(\mathrm{Rp})$ \\
\hline 1 & $117.007 .385,41$ & $32.502,05$ \\
3 & $118.307 .385,41$ & $32.863,16$ \\
4 & $114.707 .385,41$ & $31.863,16$ \\
\hline
\end{tabular}

Sumber: diolah dari data primer

Tabel 4 menunjukkan dari empat skenario yang digunakan terlihat bahwa harga pokok produksi kacang koro pedang masih berada dibawah harga jual produk senilai $\mathrm{Rp} 35.000 / \mathrm{kg}$. Selisih tingkat keuntungan diantara empat skenario yang digunakan tidak terlalu jauh, hal ini menunjukkan bahwa tingkat kepekaan biaya yang digunakan terutama bahan penolong sangat sensitif terhadap hasil perhitungan harga pokok produksi kacang koro pedang di UD Laksmi Devi. Kondisi ini dapat dijadikan bahan pertimbangan kembali dalam penentuan harga jual produk kacang koro pedang terkait komponen biaya yang tidak terprediksi setiap tahunnya.

\section{Kesimpulan dan Saran}

\subsection{Kesimpulan}

Berdasarkan hasil analisis dan pembahasan yang telah dilakukan, maka diperoleh kesimpulan bahwa harga pokok produksi kacang koro pedang pada bulan Desember tahun 2016 yang dilakukan UD Laksmi Devi per unitnya sebesar Rp 28.887,33. Analisis harga pokok produksi kacang koro pedang berdasarkan komponen biaya produksi dan non produksi menghasilkan harga pokok produksi per unit sebesar $\mathrm{Rp} 31.529,83$. Perbedaan hasil perhitungan harga pokok produksi kacang koro pedang menunjukkan selisih sebesar Rp 2.642,5. Analisis kepekaan biaya terutama biaya bahan penolong (bawang putih, minyak, gas LPG $12 \mathrm{~kg}$ ) menunjukkan tingkat sensitivitas terhadap harga pokok produksi kacang koro pedang, dilihat dari selisih perhitungan harga pokok produksi yang tidak terpaut jauh meskipun skenario yang dibuat sudah dibedakan dan disesuaikan dengan kondisi saat ini yakni peningkatan satu komponen biaya ataupun sebaliknya.

\subsection{Saran}

Berdasarkan hasil pembahasan dan kesimpulan yang diperoleh, maka saran yang dapat disampaikan dalam penelitian ini, yaitu Pihak UD Laksmi Devi disarankan untuk menggunakan hasil penelitian ini sebagai dasar untuk menentukan keuntungan, dan melakukan penganggaran biaya diatas biaya rata-rata agar tidak terjadi overbudget saat direalisasikan. 


\section{Ucapan Terimakasih}

Ucapan terimakasih ini penulis tunjukan kepada seluruh pihak yang telah membantu dalam pelaksanaan penelitian hingga karya ilmiah ini dapat dipublikasikan di e-jurnal.

\section{Daftar Pustaka}

Balitkabi. 2016. Prospek Aneka Kacang Potensial:Koro Pedang sebagai Pengganti Kedelai.[Jurnal Pertanian].www.balitkabi.litbang.pertanian.go.id. Diunduh pada Tanggal 4 Desember 2016.

BPS. 2016. Penduduk Indonesia Tahun 2016. http://www.bps.go.id/. Diunduh pada Tanggal 28 November 2016.

Bungin, Burhan. 2014. Metode Analisis Kuantitatif. Edisi Kedua. Kencana Prenamedia Group. Jakarta.

Hansen dan Mowen. 1999. Akuntansi Manajemen. Edisi ke-4. Jilid 1, diterjemahkan oleh Ancella A. Hermawan. PT.Gelora Aksara Utama. Jakarta.

Mukhyi. 2015. Pemasaran (Konsep Harga). Internet. [Modul Pembelajaran]. http://elearning.gunadarma.ac.id/docmodul/pemasaran/Bab_7.pdf. Diunduh pada Tanggal 19 Januari 2016.

Murti, Lisa Aprilia. 2015. Perhitungan Harga Pokok Produksi dengan Metode Job Order Costing pada CV. Pitulas Semarang. [Skripsi]. Universitas Dian Nuswantoro Semarang.

Rezki, Rahmad. 2014. Pengaruh Kualitas Produk, Harga, Lokasi Dan Promosi Terhadap Keputusan Pembelian Ruko Pada CV. Sinar Jaya Global Steel Padang. [Skripsi]. Universitas Tamansiswa Padang.

Simamora, Henry. 1999. Akuntansi Manajemen. Salemba Empat. Jakarta

Soekarwati. 2001. Pengantar Agroindustri. PT Raja Grafindo Persada. Jakarta

Ulfiarahmi. 2011. Teknik Pengumpulan Data. Internet. [Artikel on-line]. universitasnegeripadang.academia.edu/UlfiaRahmi. Diunduh pada Tanggal 28 November 2016. 